\title{
Verbal Bullying In The Greatest Showman Movie Directed By Michael Gracey
}

\author{
Anggraini $^{1}$, Unpris Yastanti $^{2}$, Astrida Khairani ${ }^{3}$ \\ 1,2,3 Universitas bina Sarana Informatika \\ Jl Kramat Raya No 98 Senen Jakarta Pusat 10450 \\ Corespondence email: anggraini.ngg @bsi.ac.id
}

\begin{abstract}
Abstrak. Tujuan dari penelitian pada film ini adalah untuk mengetahui penyebab terjadinya verbal bullying, dan efek terjadinya verbal bullying dalam film The Greatest Showman yang disutradarai oleh Michael Gracey. Metode penelitian ini menggunakan pendekatan kualitatif. Untuk menganalisa film penulis menonton film beberapa kali dan menggunakan teori dari buku ataupun jurnal online. Dalam film The Greatest Showman terdapat adegan kekerasan secara verbal seperti (1) Mengejek (2) Perasaan kebencian (3) permusuhan (4) Penghinaan. Sedangkan efek dari bullying terhadap korban adalah (1) Kurangnya rasa percaya diri (2) Merasa tertindas(3) Merasa terisolasi (4) Depresi berkepanjangan (5) Merasa terasingkan (6) Merasa stress. Hasil penelitian ini adalah(1) Penyebab verbal bullying adalah permusuhan, rasa tidak percaya diri dan mencari perhatian,perasaan dendam, pengaruh negative media,(2) Pengaruh bullying adalah perasaan berbeda dan penurunan percaya diri.
\end{abstract}

Kata kunci: Film; Penindasan; Penindasan Secara Lisan; Sastra.

Abstract. The purpose of the research in this movie is to determine the cause of verbal bullying and the effect of verbal bullying in the movie The Greatest Showman, directed by Michael Gracey. This method of research uses a qualitative approach. To analyze the movie the writer watched the movie several times and used the theory of books or online journals. In The movie The Greatest Showman there is a verbal violent scene such as (1) Taunting (2) A feeling of resentment (3) Hostility (4) Contempt. While the effect of bullying against victims is (1) Decreasing confidence (2) Feeling intimidate (3) Feeling isolated (4) Prolonged depression (5) Feeling dissimilar (6) Feeling stress. The results of this research are (1) the cause of verbal bullying are hostility, A sense of lack od confidence anf attentian seeking, A feeling of resentment, the Negative influence of media.(2) The Effect of bullying are Feeling disimilar and Decreasing confidence.

Keywords: Bullying; Literature; Movie; Verbal Bullying

\section{INSTRODUCTION}

Literature is often defined as a permanent expression in words of the some through or feeling idea about life and the world. Literary work can construct the world throughout world for the motivate that world have power (Roshida, 2015). Literature is someone heart expression or the mind of someone who is poured to motivate others. Literature a body of writer works related by subject-matter (e.g. the literature of computing), by language or place of origin (e.g. Russian literature), or by prevailing cultural standards of merit. In this last sense, "literature" is taken to include oral, dramatic, and broadcast compositions that may not have been published in written form but which have been (or deserve to be).(Yastanti \& Hadiyansyah, 2019).

Literature is an inseparable part of the reality of life. Literary works, particularly prose and drama, contain conflicts, events, figures, messages relating to human life" (Endraswara, 2013) . Based on the statement Endraswara, literature is a society expression that can show views to the society or related messages in life.

Based on the experts statements above, literature is an imaginative work made by the author. Literature not only tells of the thought of the author, but the history of the myth of human culture there is also entertaining sides of literary work that can make viewers feel the storyline is like sad, happy, angry or anxious. Literature can also entertain viewers who see or read.

A Movie is a social phenomenon. Many of the participants contained in a movie of the movie, then interpreted by it. Some see the movie as a result of the arts and entertainment alone, as a free space of expression in a process of learning audiences, and other groupings to interpret the movie as empirical realities which record the honest social values that occur in a society. "Movie is a series of moving pictures, recorded with sound that tells the story, shown on television or at the cinema or movie theater" (Hornby, 2010). From Hornby states, movie are thousands of images that can move and create vivid images, to create vivid images, images must capture an object.

Movie is a form of entertainment that enacts a story by sound and a sequence of images giving the illusion of continuous movement" (Arfani, 2018). It means movie is a form of entertainment or a story that is packaged using a voice or image to attract the attention of the viewer so that the audience can feel the story.

Anisti argue "The movie is an electronic signal of moving graphics pictures, or text used to combine a 
steady stream of images used for entertainment, education, or other uses. This term is often used to describe content that is longer than ten minutes or something viewers would watch on TV or at the theatre" (Yastanti \& Putra, 2019).

Movie is one of entertainment. Many people like movie, because the message is easy to understand. Through movie people can get some information, entertainment, and education" (Yastanti \& Hadiyansyah, 2019). Movie is an entertainment for everyone who watches it from the movie can get a wide range of information, education, entertainment and add to science.

Conclusion of all the opinions of the experts above the movie is one of the stories in the form of audio visual consisting of scenes that stringing the story or movie is a imagination or expression of the author that is poured through the form of audio visual. Movie also contains information that can be obtained there as well as adding science to the audience.

Bullying is an act or deed committed by a human being, both individually and collectively, that is a recurring physical, psychological, social, or verbal attack, which is carried out in a situational position of strength that is defined for their own gain or satisfaction" (Emza, 2015). Bullying of the word bully which means snapping, a person who bothers a weak person. So, that can be interpreted bullying is a deliberate behavior repeatedly and the existence of misuse of power from perpetrators.

Bullying or bully is an act when someone repeatedly becomes the subject of a negative action from a person or group of people. Bullying is a social issue that attacks not only children, but also adolescents to adults (Reyes, 2016). In other words, bullying behavior involves unbalanced strength and power, so the victim is in a state of not being able to effectively defend itself against negative actions it receives.

Bullying is the use of force, threat, or coercion to abuse, intimidate or aggressively dominate others. The behavior is often repeated and habitual. One essential prerequisite is the perception, by the bully or by others, of an imbalance of social or physical power, which distinguishes bullying from conflict. (Juvenon \& Graham, 2013).

This means bullying is a form of harassment. This consists of repeated actions involving the strength of a person or group of people to oppressive or harasses a person, a less powerful group. The purpose of this bullying is to gain power over something, not accept a uniqueness or to dominate others.

Bullying happens when physical, social or symbolic exclusion becomes extreme, regardless of whether such exclusion is experienced and or intended. One of the central mechanisms of bullying is social exclusion anxiety, which may be alleviated by the production of contempt (Schott, 2014). Social exclusion and contempt are among the phenomenon of bullying that often arises in society. It arises because some indicators such as victims that have different social status or circumstances are not the same as in general.

Bullying victims will experience psychological problems such as prolonged depression, stress, feeling dissimilar, feeling intimidated, decreasing confidence, to the feeling of wanting suicide" (Fujikawa, 2016). The difficulty of adjusting to the social environment also appeared to the victims. The most extreme of this psychological impact is the possibility of the onset of psychological disorders on bullying victims, such as excessive anxiety, always feeling scared, depressed, suicidal, and symptoms of post-traumatic stress disorder.

Bullying behavior poses a bad impact on victims and perpetrators. Bullying can make victims feel anxious and frightened. When bullying lasts long periods of time can affect self-esteem, increase social isolation, withdraw.

According to (Zakiyah, 2017) Types of bullying behavior include :

\section{Physical Bullying}

Bullying is an invisible kind of bullying. Anyone can see it because there is a physical touch between perpetrators and victim. Examples of physical bullying include: slap, choke, stomp, tackle, spit, fake, throw with the goods, punish by running around the field, punish by push-up and reject.

2. Verbal Bullying

Verbal bullying is a type of bullying which can also be detected because it can be caught the sense of hearing. Examples of verbal bullying include: bending, insulting, dub, shouted, publicly humiliated, accused, cheering, spreading gossip, defamatory and refusing.

\section{Mental Bullying}

Bullying is the most dangerous type of bullying because it does not capture eyes or ears if it is not enough caution to detect it. This bullying practice happens secretly and beyond the monitoring radar. Examples of mental bullying include: looking cynical, looking full of threats, silence, disallow, terrorize, or email a short message of a mobile phone.

From the statement above, bullying is three type are : Physical bullying this bullying uses a physical touch between perpetrators and victim such as slap, spit, hit, throw with stuff, and others. Verbal bullying this bullying usually uses the words that hurt someone heart such as defamatory, scorn, accusation, intimidation and others. Mental bullying this bullying is the most dangerous type of bullying. Bullying happens secretly and beyond the victim monitoring. Such as (terrorize, send a short message from a threatening phone or email, etc.) 
Causes of Verbal Bullying, Bullying may occur due to a prejudiced involvement between the interacting parties. Bullying is not an act that happens to happen, but it is caused by several factors. (Wardhana, 2015) Explain that bullying is caused by several factors, such as :

1. Hostility, hostility and resentment among ordinary friendships triggered bullying action.

2. A sense of lack of confidence and attentionseeking, a less confident person often wants to be noticed, one of which is with bullying. By bullying others, they will feel satisfied, stronger and more dominant

3. A feeling of resentment, someone who has been hurt or oppressed usually saves a grudge that wants to be channeled to others so that others feel the same way, one of them is to do bullying.

4. The negative influence of the media, the more graphic violence in the media is a good television, the Internet, and so also a bad example can make someone commit violence for no apparent reason.

Many factors are causes the verbal bullying behavior that happens, like a feeling of dislike with the excess of others, the feeling of envy, not confident with themself eventually leads to emerging behaviors to oppressing others.

Bullying victims will experience psychological problems such as prolonged depression, stress, feeling dissimilar, feeling intimidated, decreasing confidence, to the feeling of wanting suicide" (Fujikawa, 2016). The difficulty of adjusting to the social environment also appeared to the victims. The most extreme of this psychological impact is the possibility of the onset of psychological disorders on bullying victims, such as excessive anxiety, always feeling scared, depressed, suicidal, and symptoms of post-traumatic stress disorder.

Bullying victims will experience psychological problems such as prolonged depression, stress, feeling dissimilar, feeling intimidated, decreasing confidence, to the feeling of wanting suicide" (Fujikawa, 2016). The difficulty of adjusting to the social environment also appeared to the victims. The most extreme of this psychological impact is the possibility of the onset of psychological disorders on bullying victims, such as excessive anxiety, always feeling scared, depressed, suicidal, and symptoms of post-traumatic stress disorder.

Bullying effect can affect victims, perpetrators, and witnesses to the act of abuse itself. Bullying can have a negative impact on mental health, and even the impact can make a person have an intention to commit suicide or to attach it to the use of illegal drugs. Like Suryani explained, some of the impacts of bullying behavior can be difficult in socializing, this means that verbal bullying has a negative impact on future life for the victim. Being a victim of bullying has a high risk of experiencing depression disorders, low confidence, shy and out, feeling isolated and trying to commit suicide.

The purposes of this Analysis are to identify the cause of verbal bullying and the effect of verbal bullying in the movie The Greatest Showman, directed by Michael Gracey.

\section{METHOD}

The writer uses a descriptive method to analyze the data information in the discussion. The writer takes some theory from several books, journals, sites that support and references from other writer support in this research. The writer also cite the theory from of (Sugiyono, 2013) "A descriptive research method is a method of study done to know the value of independent or more self-variables without making comparisons or combining one variable with another".

The writer does some procedure. First, the writer begins the analysis by watching a movie showing the act of Verbal Bullying, an act that demonstrates suppression. Then, the results of observations taken by the writer, evaluate again to find the problem in the movie and the last, the writer collects data that will be analysis, looking for theories based on the experts through books or files that support in the related problems in The Greatest Showman Movie Directed By Michael Gracey

\section{FINDING AND RESULT}

The writer uses the theory in Introduction to identify the causes of verbal bullying. Below are the scenes of the causes of verbal bullying according to (Wardhana, 2015).

\section{Hostility}

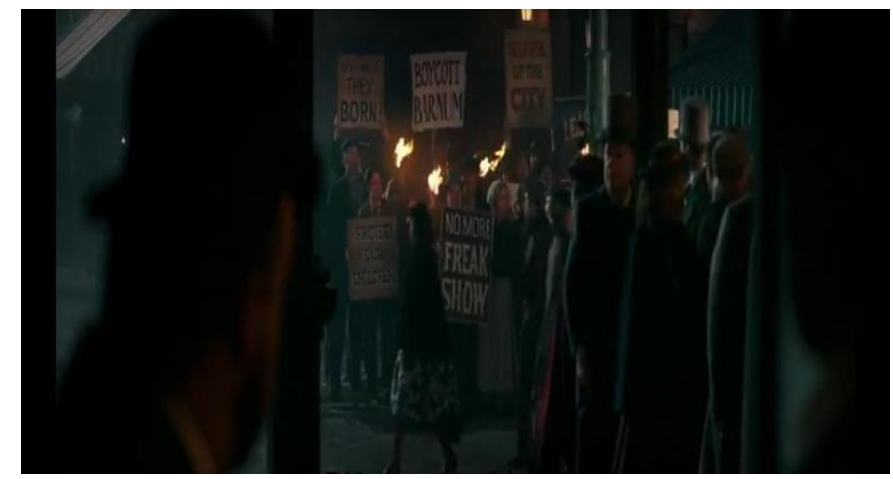

Figure 1. Some people opposed to circus performance

O"Malley : "A bit of nasty element"

Barnum : "There always is, isn't there? Nothing draws a crowd quite like a crowd."

Community : "We don't want you in our city! Go home, you freaks! freaks!" 
This scene began when O'Malley summoned P.T. Barnum to see the conditions outside the building where he and his members of the circus performed. When it came to the front of the building, P.T. Barnum saw a lot of community carrying some demo tools such as, the board reads "boycott Barnum", "no more freak show", "protect our children", some carry fire torch. Barnum felt a shock about the incident and the community said "We don't want you in our city! Go home, you freaks! Freaks!"

The incident identifies that because the occurrence of verbal bullying is a performance that uses the services of people who have physical or unique circus, but the community considers the uniqueness is an oddity that can bring losses, so that the hatred arises and the hostilities that the community is.

\section{A sense of lack of confidence and attention-seeking}

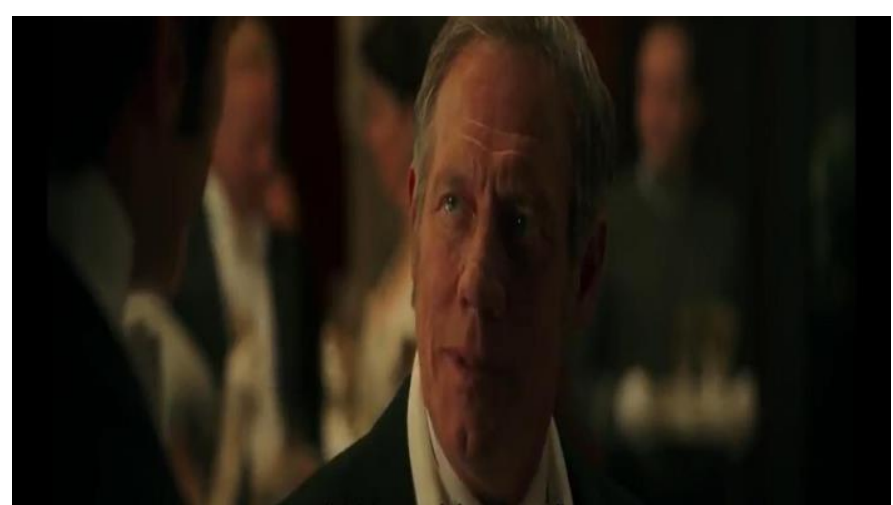

Figure 2. Mr. Hallet demeaning P.T. Barnum in the party

Mrs. Hallet : "Are these?"
Barnum : "Yes, yes, those are your
granddaughters" "'Phineas, not here."
Charity : "Not here? You afraid I am gonna
Barnum
embarrass your parents in Front of their fancy friends? I
really don't think I have that power. An insignificant
man like me who was clearly destined to lead an
insignificant life."
Mr. Hallet : "All that fortune, and still just the tailor
boy."

For the success, P.T. Barnum finally formed a partnership with famous Swedish singers. She is named Jenny Lind or her nickname is "Swedish Nightingale". Lind had a very impressive voice and made P.T. Barnum intending to cooperate with him and invited him at the party of the success of P.T. Barnum.

Many of the upper-middle class invited guests came to the success event of P.T. Barnum, no exception Mr. Hallet and Mrs. Hallet, they were the parents of Charity Barnum. Mr. Hallet approached P.T. Barnum and admitted to the success of P.T. Barnum, but at once Mrs. Hallet saw the Charity with her two daughters and asked if it was her daughters .
P.T. Barnum also answered they were the granddaughters of Mr. Hallet and Mrs. Hallet and P.T. Barnum also had a round of his past that had been humbled by Mr. Hallet in front of the invited guests. Mr. Hallet felt cornered and did not accept the words P.T. Barnum and Mr. Hallet said "All that fortune, and still just the tailor boy."

Mr. Hallet stance shows that he is not confident and seeks to seek attention to the guests of the invitation to impartially pay the P.T. Barnum. The scene shows if verbal bullying can happen from a person who has low confidence and wants to treat others lower than that and finally he is satisfied with the action.

\section{A feeling of resentment}

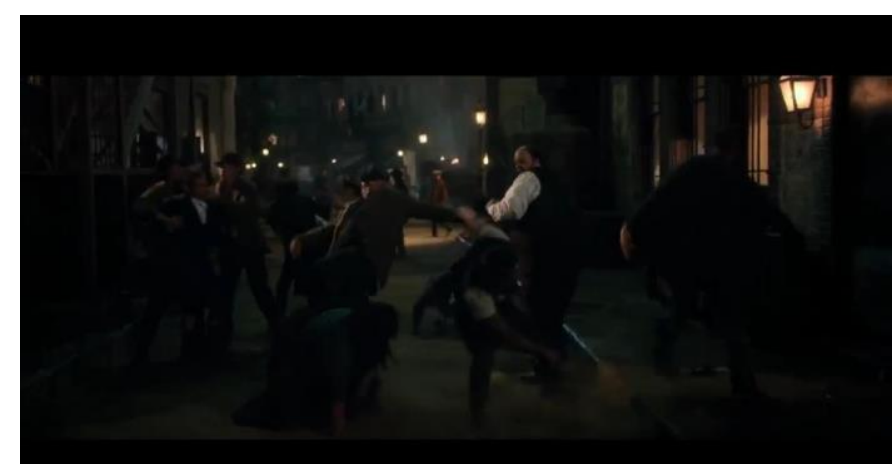

Figure 3. Some peoples persecuting P.T. Barnum members

Man

: "That's right, fat boy! You gonna protect that bearded lady?"
Barnum
: "Hey! Hey! That's enough!"
Man
: "Freaks!"
Barnum : "Walter! Inside, all of you. Right now"
Peoples : : "Look at they run! We don't want your
kind! Get out a here! That's right, you freaks! Your master calling!"”
Barnum : :That's quite enough, sir"
Man : "Nothing more to look at!"

Seen a group of people led by a man who attempted to injure a member of P.T. Barnum, Lettie Lutz, a bearded woman and a fat man nicknamed the Lord of Leeds who attempted to protect Lettie Lutz.

Unfortunately, a man from the group attacked the ruler of Leeds and said "That's right, fat boy! You gonna protect that bearded lady?", "Freaks!". So many times P.T. Barnum tried to stop their action until they finally stopped and a man from the group said "Look at they run! We don't want your kind! Get out a here! That's right, you freaks! Your master calling!".

The scene shows a verbal bullying behavior aimed at one of the members of the circus P.T. Barnum, Lettie Lutz. She got bad behavior from a group of people who hated Lettie existence. They thought Lettie had an abnormal physique because she had a beard on her face and had dared to appear in public. From that attitude, a group of people resented to Lettie. 


\section{The negative influence of the media}

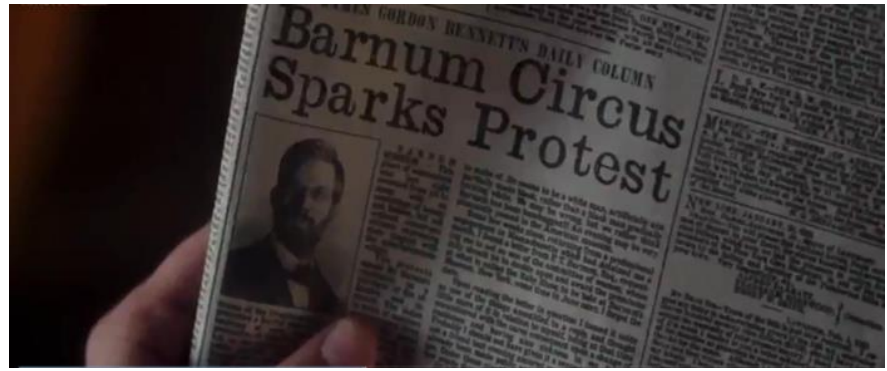

Figure 4. News about P.T. Barnum and the Circus

Barnum : "Shame of the city. The protests cement Mr. Barnum reputation as a purveyor of the offensive and indecent."

Lettie : "Offensive and indecent. Mr. Bennett, I am blushing" Charity : "What do you care what Bennett thinks?"

Charles

: "He is a prig and a snob."

Barnum : "Yeah, and all the snobs in New York read him. He does their thinking for them"

In the morning, P.T. Barnum and the members were gathered and conversed as usual. P.T. Barnum who was holding the newspaper, found a news about him and his circus on the front page of the newspaper. The news in the paper reads "Shame of the city. The protests cement Mr. Barnum reputation as a purveyor of the offensive and indecent". The news was written by a man named James Gordon Bennett.

$\mathrm{He}$ is a founder, editor, and also a publisher of the New York Herald newspaper. Mr. Bennett has never liked the existence of P.T. Barnum and also his circus, he considers the show to be very nasty to see and be shown public.

Mr. Bennett leverages his power in the media to make news that always corner P.T. Barnum as well as his circus to cease not to show or display the nasty thing. This scene clearly shows the verbal bullying behavior towards P.T. Barnum as well as the circus of which Mr. Bennett makes the news that always corner P.T. Barnum and his circus.

Of the several scenes above there are four signs that are diagnosed as the cause of verbal bullying behavior to P.T. Barnum and the circus members. The writer thinks this scene depicts a situation where perpetrator verbal bullying know that they have more power and excess so they can perform verbal bullying actions against P.T. Barnum and the circus members

\section{The Effect of Verbal Bullying}

The writer uses the theory in Introduction to identify the effect of verbal bullying. Below are the scenes of the causes of verbal bullying according to (Fujikawa, 2016).

\section{Feeling Dissimilar}

Data 1

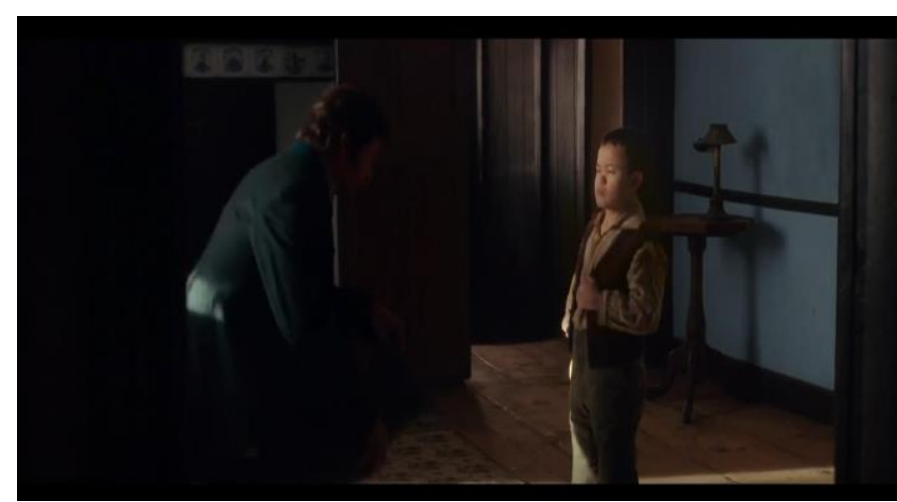

Figure 5. P.T. Barnum meet Charles Stratton

Barnum : "P.T. Barnum, at your service. I am putting together a show and I need a star"

Charles : "You want people to laugh at me"

P.T. Barnum met Charles Stratton. P.T. Barnum introduced himself to Charles, he said that he had a show and he needed a star at his show. However, Charles refused and said "You want people to laugh at me".

The scene was shown to Charles attitude towards P.T. Barnum who felt dissimilar from the others. Because his physique is not like other people who are perfect. Charles felt that different physique from others would embarrass him and feel dissimilar from the social environment.

\section{Decreasing Confidence}

Data 2

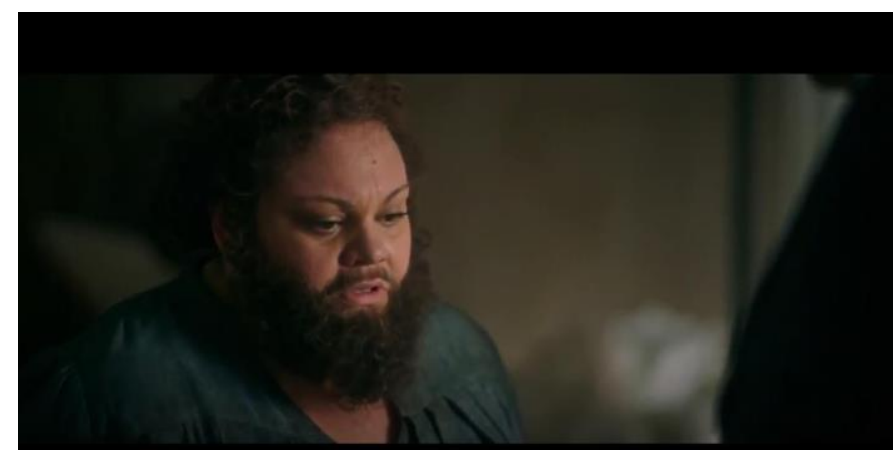

Figure 6. Lettie Lutz feel decreasing confident

Barnum : "You are so talented, blessed.. extraordinary. Unique. I would even say beautiful"

Lettie : "Sir. Please leave me alone." Barnum : "They don't understand, but they will."

When P.T. Barnum posted a poster advertisement looking for a unique person. P.T. Barnum got the address of one who had a unique physique from a person, eventually P.T. Barnum and his daughters went to the place of Female Dorm to meet Lettie 
Lutz. He approached Lettie, and was amazed by the very unique state of Lettie.

But, sadly many were laughing at Lettie over praise from P.T. Barnum. Lettie said "Sir. Please leave me alone" and asked P.T. Barnum to leave her alone. The attitude shown by Lettie to P.T. Barnum is a decreasing confidence to others who see the condition that has a beard on her face.

From the data and explanation above, the writer concluded that someone who is experiencing verbal bullying either in a painful way or acquiring bad behavior from the environment will severely affect the victim mental or psychic. Seen from the several scenes of the circus members P.T. Barnum was treated unfairly and not well by the surrounding community because of the uniqueness they had. Some people consider this uniqueness to have a devastating impact and influence on the environment and attempt to expel P.T. Barnum and circus members in order to leave the New York City. From the attitude made by some New York society finally the circus members

P.T. Barnum feels like useless, feel isolated, embarrassment will meet others, always imagined to be exiled by people around.

\section{CONCLUSION}

After analyzing the movie the writer found several causes of verbal bullying in The Greatest Showman Movie such as hostility of circus member

P.T. Barnum have a different physical condition than others, the uniqueness that exists in themselves becomes a negative influence for people and the media in New York City, a feeling of resentment peoples of New York City without their existence in public without shame, and the last is a sense of lack of confidence of some who disliked P.T. Barnum and his circus members eventually led to verbal acts of bullying.

Meanwhile, the effects of bullying to P.T. Barnum and the members the writer find two effects of bullying. The first is to feel decreasing confidence when meeting people, the second is feeling dissimilar from the others.

\section{REFERENCE}

Arfani, S. (2018). The Schizophrenia in The Main Character of A Beautiful Mind Movie Directed by Ron Howard. Wanastra, 9-16.

Emza, E. (2015). Fenomena Bullying. Fenomena Bullying Sekolah Dasar Kawasan Beresiko Kota. 60-62.

Endraswara, S. (2013). Metodologi Kritik Sastra. Metodologi Kritik Sastra. Yogyakarta : Ombak.

Fujikawa, S. dkk. (2018). Disciplinaryslappingisassociatedwithbullyinginvol vement. JournalofAdolescence, 207-216.

Hornby. (2010). Oxford Advance Learner" Dictionary. Oxford Advance Learner' Dictionary, 8th. United Kingdom. United Kingdom: Oxford.
Juvenon, J. \&. (2013). Bullying in Schools : The Power of Bullies and the Plight of Victims. Annual Reviewof Psychology.

Reyes. (2016). A Basis for Formulating School Policy. aijcrnet.

Roshida, R. (2015). nderstanding al- Mutanabbi. A Humanistic Pyschological. Universiti Sains Malaysia.

Sugiyono. (2013). etode Penelitian Pendidikan. Metode Penelitian Kuantitatif, Kualitatif dan $R \& D$. Bandung: Alfabeta.CV.

Wardhana, K. (2015). Buku Panduan Melawan Bullying. Jakarta: Sudah Dong Community.

Yastanti, U., \& Hadiyansyah, I. (2019). Loyalty of The Main Character In The Choice Movie Directed By Ross Katz. Wanastra, 11(2), 191-200.

Yastanti, U \& Putra, Virky SD. (2019). Leadership in Fury Movie Directed by David Ayer. Eralingua: Jurnal Pendidikan Bahasa Asing dan Sastra,3 (2),94-104

Zakiyah Ela, H. S. (2017). Faktor Yang Mempengaruhi Remaja Dalam Melakukan Bullying. Jurnal Penelitian dan PPM. 